\title{
A Flexible Approach to the EGP Syllabus: Why It Is Possible
}

\author{
Concilianus Laos Mbato \\ ELESP - Sanata Dharma University \\ c.laosmbato67@gmail.com
}

\begin{abstract}
Curriculum, and its ensuing syllabus, may reflect various competing ideologies rather than merely being a vehicle to promote quality teaching and education. In practice, English teachers may have to encounter and confront an imposed curriculum, and syllabus, in thier EGP classes. Despite such imposition, this article argues that they can and should adopt a flexible approach to the document in order to cater for learners' varied and changing learning needs. To achieve the aim, this article draws on theories of curriculum and discusses core issues in the teaching of English for Specific Purposes. A particular focus is then given to teaching practices in EGP classrooms where teachers interpret and implement a curriculum. A flexible model to the syllabus is offered.
\end{abstract}

Keywords: EGP (English for General Purposes), ESP (English for Specific Purposes), Curriculum, Ideologies, Syllabus, Needs analysis, and a flexible approach.

\section{INTRODUCTION}

The teaching learning processes in the classroom are inseparable from the curriculum, and its syllabus. In the Indonesian educational context, the school curriculum has undergone several changes. In the past few years alone, the Indonesian government, through the ministry of education and culture, has introduced three curricula, with the 2013 curriculum being the latest one. These changes underscore the crucial role curriculum plays in the process and production of quality teaching and education.

The relevance of curriculum, and its syllabus, with the teaching learning processes in the classroom is accentuated by Hamilton (1999). He (1999, p. 42) stresses curriculum as a storehouse which is unpacked and repacked through teaching and learning respectively. Through teaching, teachers bring stored up experience to life so that it can be grasped by learners. They unlock the potential of the curriculum with the learners reshaping themselves in the light of the curriculum potential. Viewed this way, the curriculum, with its syllabus, serves to translate the experience of learning into a form accessible to learners. Learners will accomplish learning when they can link their own prior experience with that offered by their teachers.
This article argues for a flexible approach to the curriculum, and its subsequent teaching syllabus. It begins with a delineation of theories of curriculum, and syllabus, and is followed by a brief discussion of English for specific purposes and informed practices in EGP classes around the world as regards curriculum and syllabus. A model for a flexible approach to the curriculum culminates the discussion. This paper ends with some conclusions and suggestions.

\section{CURRICULUM}

Experts in the area of curriculum provide different yet complementary explanations of this construct. The various conceptions of curriculum reflect social ideologies about the role of schooling in society, the nature of knowledge and learning, and the roles of teachers and learners (Adamson and Morris, 2007, p. 267). Adamson and Morris (2007, p. 267) outline six ideologies that may shape the curriculum: academic rationalism, social and economic efficiency, social reconstructivism, orthodoxy, progressivism, and cognitive pluralism. Academic rationalism focuses on enhancing learners' intellectual capabilities and cognitive skills, and on teaching them how to learn. It 
emphasises testing of learners' knowledge and skills. Social and economic efficiency stresses the human capital in society and aims to develop learners' ability to apply knowledge and skills. Social reconstructivism views the curriculum as the agent for social reform, change and criticism, and involves learners in the assessment. Orthodoxy introduces learners into particular religious or political beliefs. Progressivism provides learners with opportunities for enhancing their personal and intellectual development through qualitative measures with the analysis of the process of learning as its driving force. Cognitive pluralism promotes multiple competencies and attitudes through qualitative measures which are enabled through diversity of learning.

Curriculum, and syllabus, may be viewed as a specific social reality which is acted on and transformed by the teacher and is not merely something imposed on teachers' and pupils' classroom practice (Young, 2008, p. 23). Short and Burke (2014, p. 18) perceive curriculum as inquiry, which involves theoretical and practical shifts in the way teachers view teaching and learning within school contexts. In this perspective, teachers gain control of their learning, which empowers them to continuously examine their beliefs and actions in their interaction with students in order to create more democratic learning environments. These learning environments encourage students to become inquirers as they explore and find the questions that are most significant in their lives. At the heart of inquiry is a collaborative relationship, and not the hierarchies of control.

Through inquiry, Short and Burke (2014, p. 38) emphasise education for democracy. A democratic education believes in the natural inquisitiveness of the people and realises that the significance of learning lies in what people do and why they do it. It also accepts new alternatives without undermining the contributions of current and past beliefs. In this education environment each individual assumes a responsibility to critique, envision, and pose problems while at the same time value and seek diversity, and not sameness. Democratic education creates room for diversity and creativity in viewing and implementing curriculum, and syllabus.

Rather than being a vision only, curriculum is viewed as a cultural tool which is shaped by its users (Hamilton, 1999, p. 38). A curriculum is both a route to the future and a set of procedures to implement curriculum goals. As a powerful tool in education, curriculum may reflect the assumptions and aspirations of the powerful group in the society rather than the powerless one. To anticipate the negative impacts of the imposition of certain power groups in the curriculum, teachers need to own the power to modulate, transpose and if necessary substitute learning goals. The delegation of power in interpreting the curriculum will enable the students' experience to inform and be informed by the syllabus (Hamilton, 1998, p. 41). Treating the curriculum from a document to the experience in the classroom will enable students to develop into a flexible thinker (Golsby-Smith, 2013, p. 76).

The benefit that may result from the increasing power delegated to the teacher is reflected below (Gibbons, 2009, p. 29):

If we can dream for a moment that some increasing power over curriculum and assessment returns to the teaching profession, then it seems to me imperative that the kinds of cross-phase, cross-institutional, nonhierarchical networks ... be allowed to redevelop. Then, perhaps, we might strive again for ways of assessing children that are based on the experience of subject experts, rooted in classroom research, and that place children's needs and interests at the heart of the assessment process.

In a similar vein, Finney (2002) and Kneller (1964) suggest a progressivist approach to the curriculum and syllabus. Progressivism places stress on the process of learning. The process model enables the individual to progress towards self-fulfilment. It is concerned with the development of understanding, and not just the passive reception of knowledge or the acquisition of specific skills. It has been marked by the move towards a learner and learning-centred curriculum (Finney, 2002, p. 73). Kneller (1964, 
p. 96) discusses six principles of progressivism in education: 1 ) education has to be active and is related to the interests of the child; 2) education must be a project-based activity in which a child is trained to solve concrete problems; 3 ) education is not only to prepare children to live later on in society but is already life itself; 4) the teacher functions more as a facilitator or adviser rather than as a person of authority; 5) every individual will produce better results when they are working together than when they are competing; 6) Education and democracy are inter-related, so schools should be managed democratically.

While the definitions and descriptions of curriculum are diverse, in practice, there is no single syllabus nor is there a single curriculum at play in the classroom (Hutchinson and Waters, 1987). Adamson and Morris (2005, p. 269) argue:

Clearly, these ideologies (of curriculum) can in principle and practice be exclusive. A curriculum could be constructed that is driven by a single ideology, such as fascism. However, in pluralistic societies and institutions, the curriculum is influenced by a combination of ideologies - and these may be contradictory rather than consistent. There is also a tendency for curricula to maintain links to traditions, even though radical changes may be incorporated in curricular reform. As a result, a curriculum is often a complex set of tensions and contradictions that is shaped by ideological, historical and educational forces.

Ideological, historical and educational forces have shaped and reshaped English language teaching since the end of the Second World War. This has led, among others, to the emergence of English for specific purposes, which in turn contributes to the teaching of English for General Purposes.

\section{ENGLISH FOR SPECIFIC PURPOSES}

English for specific purposes is defined as an approach to language teaching in which all decisions, as to content and methods, are based on the learners' reason for learning (Hutchinson and Waters, 1987, p. 19). Two important domains of ESP will be briefly discussed, i.e. reasons for the emergence of ESP and needs analysis.

\section{Reasons for The Emergence of ESP}

Basturkemen (2006, p. 133) discusses specific objectives of ESP that led to its emergence, i.e. to reveal subject-specific language use, to develop target performance competencies, to teach underlying knowledge, to develop strategic competence, and to foster critical awareness. Hutchinson and Waters (1987, pp. 6-8) mentioned the demands of the Brave New World, a revolution in linguistics, and a focus on the learner as the three reasons common to the emergence of ESP. The Brave New World was marked by two key historical periods which brought ESP to life, i.e. the end of the Second World War and the Oil Crisis in the early 1970s. While the former event boosted people's motivation to learn English for successful international communication, the latter put pressure on the teaching profession to deliver English to meet business purposes. English became subject to the wishes, needs and demands of people other than language. Revolution in linguistics was marked by a shift from describing the features of language to a focus on the ways language was used in real communication and in various contexts. Psychology became the third impetus; it inspired language instruction design to focus on learners. Learners and their attitudes were put at centre stage. Learners were seen to possess different needs and interests, which would influence their motivation and the effectiveness of learning. Thus teaching English should be tailored to meets learners' different needs, interests and motivation. The tool to address learners' needs is needs analysis.

\section{Needs Analysis: A Contribution of ESP to EGP}

Needs analysis has become a crucial attribute of English for specific purposes since its emergence. Basturkmen (2006, p. 1) defines needs analysis as the identification of difficulties and standard situations by observation of participants functioning in a target situation. Needs analysis aims to establish the "what" and the "how" of a course, before the design of curriculum, materials selection, methodology, assessment, 
and evaluation (Flowerdew, 2013, p. 325). A comprehensive needs analysis and a flexible learning-centred curriculum will ascertain students' equal reception of a balanced diet of language (Gatehouse, 2004, p. 7). Understanding learner needs enables the teacher to create a successful program (Thanasoulas, 2004, p. 8). It is seen as the logical starting point for the development of a language program (Finney, 2002, p. 75).

A comprehensive classification of needs analysis is offered by Hutchinson and Waters (1987, pp. 54-56). Learners' needs are grouped into target and learning needs. Target needs describe what the learner needs to do to function in the target situation, while learning needs are what the learner needs to do in order to learn. The target needs situation is further classified into necessities, lacks and wants. Necessities are the needs determined by the demands of the target situation, that is, what the learner has to know in order to function effectively in the target situation. Lacks are the gaps between the target proficiency and the existing proficiency of the learners. Wants are learners' views on the necessities and lacks which might conflict with those of other interested parties.

In sum, needs analysis raises ESP teachers' awareness of the various learners' and learning-needs, interests, reasons and goals for learning and prompts them to act accordingly.

\section{TEACHING PRACTICES IN EGP CLASSES}

As many curricula, and their ensuing syllabuses, are prescribed by the government, teachers may find themselves having little power over what, how, why and when to teach language elements and skills other than those stipulated in these documents.

A recent study on English language teaching in five senior high schools in Indonesia, involving 258 students (Marcellino, 2008), describes Indonesian students' cultural values (which may reflect the underlying curriculum and syllabus) as inhibiting learning in the following ways:
Total obedience, unquestioning mind, and the belief that the old know all as well as that the teacher can do no wrong normally portray the learning atmosphere in many classes under study. Accordingly, the class hardly raised any question to the teacher, scarcely responded critically to the teachers' debatable and unsound statement or argument; instead they respectfully and compliantly did the teacher's instructions and believed that what was said was entirely correct (Marcellino, 2008, p. 58).

A study by Lamb (2004) on Indonesian students in EGP classes found the students' openness to the increasing learning opportunities in the local environment is often not recognised in local curricula due to its focus on a rigid diet of language items transmitted by teachers and their textbooks and national exams.

Other studies indicate the teachers' more flexible approach to the teaching syllabus in EGP classes. Mbato (2013) found that the teachers were willing to revise the syllabus as a response to the learners' learning needs. Their flexibility to the syllabus resulted, among others, in learners' empowerment to take charge of their EFL learning. Wette (2010) discovered teachers' constant responses to learners' developmental and affective needs regardless of the constraints they might face in teaching. Another study (Wette, 2011, p. 136) demonstrated teachers' tensions generated by the competing demands of learners' requirements, contextual constraints, syllabus specifications, and their own theories of best practice, all of which may impact the implementation of the curriculum and syllabus in the classroom. Jones (2007, p. 54) found teachers' reading of official curriculum differently in classroom settings. Criado and Sanchez (2009, p.1), in their analysis of the compatibility between ELT textbooks and official regulations from the government (which focuses on CLT), discovered some degree of dissociation between the two and suggested such discrepancy as the reflection of the complexity of language learning. In preparing a syllabus for an Advanced Writing Course, Altay (2010) urged for a questionnaire be distributed to both the teachers and students to gain their views about the syllabus 
for the class. Kranhke (1987, pp. 67-68) discussed the complexity a teacher and students have to face in the classroom with respect to the syllabus. On one hand, they need to contend with the theoretical expectations of a syllabus. On the other hand, the syllabus also creates a relationship between the syllabus, the teacher and students. Such a relationship will inevitably frame and shape learning. Golsby-Smith (2013, p. 68) urges teachers to consider flexibility in learning that learners need to have in relation to the syllabus. Mbato (2004, p. 267) argued for an adoption of a learning-centred approach to the teaching syllabus in EGP classes. He adapted a learning centred model proposed by Hutchinson and Waters (1987) as the starting point for the teachers' flexible approach to the teaching syllabus in EGP classes.

\section{TOWARDS A FLEXIBLE EGP SYLLABUS MODEL}

The following model (modified from Hutchinson and Waters, 1987, and Mbato, 2004) depicts the necessary steps for the ESP principled-instruction in EGP classes:

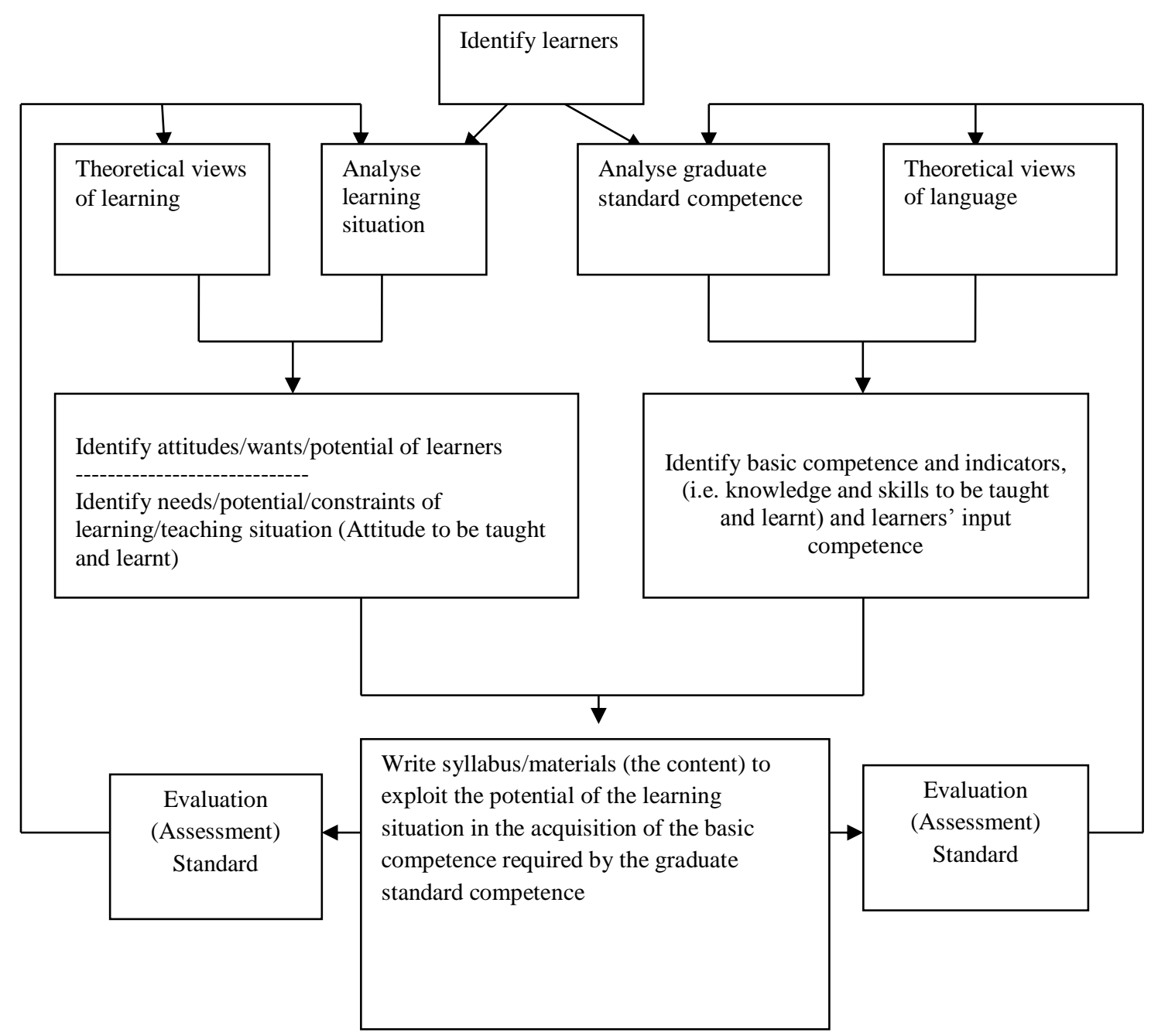

Figure 1: A flexible approach to syllabus (adapted from Hutchinson and Waters, 1987, and Mbato, 2004).

The above diagram emphasises the importance of identifying learners, i.e. the learning situation and the graduate standard competence. An analysis of the learning situation focuses on the affective elements of the learners, that is, their attitudes, wants, learning potential, and constraints. An analysis of the learning situation, and the learners' 
affective states, will give the teachers a comprehensive view of learners' psychological readiness for learning English in their classes. The importance of affective states in learning cannot be overstated (see e.g. Mbato, 2013; Phelps, 2002; Hutchinson and Waters, 1987). In order to be able to perform these activities well, the teachers need to equip themselves with sufficient knowledge of various learning theories.

Following an analysis of the affective states (attitudes) is an analysis of the graduate standard competence. This activity will then lead to some identification of basic competences and indicators, vis-a-vis knowledge and skills to be taught and learnt, and should be guided by sound theoretical views of language, be it as a system of rules (structure), a set of functions, or discourse. This should be accompanied by an analysis of learners' input competence. The focus is on determining how much learners have mastered the designated competence, which results in the identification of existing gap proficiency of every individual learner. The finding will be used as an input for the design and/or adaptation of a syllabus and learning materials. These activities may be performed at the beginning of the semester, while the teaching learning process is underway, and at the end of the term.

After performing some analyses of the learning situation (affective elements) and competences (vis-a-vis knowledge and skills), the teachers may start designing, or in case a syllabus is already available, revising the teaching syllabus, and writing and/or compiling the learning materials. The syllabus and the learning materials make use of the potential of the learning situation in the acquisition of the basic competences required by the graduate standard competence. Some evaluation/assessments compatible with the learning situation and the required competencies (knowledge and skills) will need to be designed.

Teachers should regularly assess the suitability of and revisit the syllabus and learning materials since learning needs and learners' competence may change even within a few weeks of instruction. In the studentcentred learning, where learners and learning becomes the centre of instruction, classroom syllabus should be tailored to learners' varied and changing learning needs. Research by Mbato (2013) indicated, among others, that teachers' flexible attitude to the learning syllabus leads to learners' engagement and empowerment in English language learning.

EGP class teachers should involve learners in the whole teaching and learning enterprise. Although the curriculum and its syllabus might be imposed on them, their flexibility to teaching should not be constrained by such a prescription. Many teachers around the world has demonstrated their power and creativity to tailor their teaching to learners' and learning needs regardless of this constraint. Rather than focusing on meeting the prescribed curriculum and syllabus demands per se, teachers need to view curriculum simultaneously under the lens of academic rationalism, social and economic efficiency, social reconstructivism, progressivism and cognitive pluralism, and incorporate them into a needs-based teaching syllabus since the differences between curricula are clear in theory, but might not be straightforward in practice. To accomplish this, they need to undertake a flexible approach to the teaching syllabus.

\section{CONCLUSION}

This article has argued for a flexible approach to the teaching syllabus in EGP classes. To reach the aim, it has discussed various views of curricula, and syllabus. It has also reviewed the teaching of English for Specific Purposes, and how a needs-based approach in ESP classes can illuminate English language teaching in EGP classes. A discussion on how teachers around the world implemented English curriculum, and syllabus, in their respective EGP classes sheds light on the possibility of a syllabus being more than a prescribed document. A syllabus model offered in this paper underscores the possibility and the necessity for the teachers' adoption of a flexible stance to the English syllabus. More research on how teachers 
implement the English curriculum and its subsequent syllabus in their EGP classes suited with the Indonesian education context is needed. This will enrich and empower the teachers in devising the teaching learning program that meets the learners' learning needs despite working under an imposed curriculum.

\section{REFERENCES}

Adamson, B. \& Morris, P. (2007). Comparing curricula. In M. Bray, B. Adamson \& M (Eds.), Comparative education research: Approach and methods (pp. 263-282). Hongkong: Springer.

Altay, I.F. (2010). A suggested syllabus for advanced writing skill at English language teaching departments. H.U. Journal of Education, 39, 20-31.

Basturkmen, H. (2006). Ideas and options in English for specific purposes. Mahwah, NJ: Lawrence Erlbaum Associates.

Criado, R. \& Sanchez, A. (2009). English language teaching in Spain: Do textbooks comply with the official methodological regulations? A sample analysis. IJES, 9(1), 1-28.

Finney, D. (2002). The ELT curriculum: A flexible model for a changing world. In J. C. Richards and W. A. Renandya (Eds). Methodology in language teaching. Anthology of Current Practice. Cambridge: Cambridge University Press.

Flowerdew, F. (2013). Needs analysis and curriculum development in ESP. In B. Paltridge, and S. Starfield, Handbook of English for Specific Purposes (pp. 326-345). Malden, MA: Wiley-Blackwell.

Gatehouse, K. (2004). Key issues in English for specific purposes curriculum development. Retrieved September 28, 2004, from http://iteslj.org/Articles/Gatehouse-ESP.html.

Gibbons, S. (2009). Back to the future? A case study in changing curriculum and assessment:

The story of the London association for the teaching of English's alternative ' $O$ ' level English language paper. English in Education, 43(1), 19-31.

Golsby-Smith, S. (2013). Singing from the same songsheet: The flexible thinker and the curriculum in the 21st century. English in Education, 47(1), 66-78.

Hamilton, D. (1999). Learning about education: An Unfinished curriculum. Philadelphia, PA: Open University Press.

Hutchinson, T \& Waters, A. (1987). English for Specific Purposes. A learning-centred

Approach. Cambridge: Cambridge University Press.

Jones, P. (2007). Lessons of the local: Primary English and the relay of curriculum

knowledge. Australian Journal of Language and Literacy, 30(1), 54-68.

Kneller, G.F. (1964). Introduction to the Philosophy of Education. New York: Jon Wiley \& Sons, Inc.

Krahnke, K. (1987). Approaches to Syllabus Design for Foreign LanguageTeaching.

Language in Education: Theory and Practice. Washington: Eric Clearing House.

Lamb, M. (2004). 'It depends on the students themselves': Independent language learning at an Indonesian state school. Language, Culture and Curriculum, 17(3), 229-245.

Marcellino, M. (2008). English language teaching in Indonesia: A continuous challenge in education and cultural diversity. TEFLIN Journal, 19(1), 57-69. 
Mbato, C.L. (2004). ESL/EFL Instruction: A convergence of target and learning needs. The $9^{\text {th }}$ ESEA Conference Proceedings, 257-270. Yogyakarta: Sanata Dharma University.

Mbato, C.L. (2013). Facilitating EFL learners' self-regulation in reading: Implementing a metacognitive approach in a higher education context. EdD thesis, Southern Cross University, Lismore, NSW.

Phelps, R. A. (2002). Mapping the complexity of learning: Journeying beyond the teaching for computer competency to facilitating computer capability. PhD thesis, Southern Cross University, Lismore, NSW.

Short, K.G. \& Burke, C.L. (2014). Curriculum as inquiry. Retrieved March 6, 2014, from

Http://www.coe.arizona.edu/sites/default/curriculum_as_inquiry.pdf. 18-40.

Thanasoulas, D. (2004). Classroom: Forum or arena? Retrieved October 11, 2004, from http://www/tefl.net/Articles /classroom.htm.

Wette, S. (2011).Product-process distinctions in ELT curriculum theory and practice. ELT Journal, 65(2), 136-144.

Wette, S. (2010). Professional knowledge in action: How experienced ESOL teachers respond to feedback from learners within syllabus and contextual constraints. System 38, 569-579.

Young, M.F.D. (1998). The Curriculum of the future from the new sociology of education to a critical theory of learning. London: Palmer Press. 